\title{
Śląsk i jego mieszkańcy w oczach Polaków w służbie Napoleona I
}

Tomasz Ślęczka 
nAPOS Seria XI 2005

\section{Tomasz Ślęczka}

\section{Śląsk i jego mieszkańcy w oczach Polaków w służbie Napoleona I}

$\mathrm{P}$ rzedmiotem niniejszego szkicu jest prezentacja sposobu widzenia jednej z dawnych polskich ziem, przez kilkaset lat pozostającej poza polskimi granicami, mianowicie Sląska (w jego pełnym kształcie). Ogląd ten dokonywany będzie oczami bardzo specyficznej kategorii postaci, mianowicie przyjdzie nam zajrzeć na karty wspomnién polskich żolnierzy, służących w armii napoleonískiej, ze szczególnym uwzględnieniem wojsk Księstwa Warszawskiego. Autorzy, do których przyjdzie nam się odwołać, pełnili służbę w różnych formacjach: w armii Księstwa Warszawskiego, w jednostkach polskich, znajdıjących się w słuzbie francuskiej, w jednostkach stricte francuskich, wreszcie zaś w zbrojnych formacjach krajów z Francją sprzymierzonych i wystawiających whasne oddzialy pomocnicze. Z natury rzeczy będą to przede wszystkim wspomnienia oficerów, jako że - zważywszy na stan dziewiętmastowiecznej oświaty - piśmienność nie byla wówczas stanem powszechnym. Dodatkowo zauważyć należy, że jednym z podstawowych warunków awansu oficerskiego w armiach napoleońskich była (obok osobistej dziclności) mmiejętność czytania i pisania. Zważywszy zaś na dodatkową, polską specyfikę, przejawiającą się w tym, iz stanowiska oficerskie obsadzali przede wszystkim członkowie stanu szlacheckiego i potomkowie rodzin magnackich, nietrudıo dociec powodów, dla których to przytłaczająca większość pamiętników pochodzi z kręgów oficerskich.

Najsamprzód wypada poczynić kilka zastrzeżeń. Po pierwsze, podstawa tekstowa mojego opracowania nie jest kompletna. Ogranicza się do dziel wydanych drukiem od końca XIX stulecia do czasów dzisiejszych, z pominięciemn źródeł rękopiśmiennych. Ponadto nadmienić należy, iż edycje dawniejsze, z XIX i początków XX wieku, cechują się nierzadko ograniczoną przydatnością. Aparat krytyczny z reguły jest w nich nieobecny bądź symboliczny. Niektóre dzieła wydane są w postaci skróconej, niekiedy nawet bez uprzedzania o tym czytelnika (albo skrócone mi mo zapewnicnia, że edycja jest kompletna, jak czynil 
skądinąd zasłıżony Józef Ignacy Kraszewski). W grę wchodzi ponadto cenzura, zwłaszcza w przypadku wydań pochodzących z terenów zaboru rosyjskiego (choć kwestia śląska moglaby mieć tı marginalne znaczenie, zatem i ingerencje cenzorskie pewnie byly symboliczne bądź nie było ich wcale, bez szczególowego porównania rękopisu z tekstem wydanym stwierdzić tego niepodobna; niestety, nie zachowały się wszystkie rękopisy).

Po wtóre, tematyka śląska ma kartach tychize tekstów pojawia się incydentalnie, a jeżeli już uważnemu czy telnikowi przychodzi natrafić na ślad obecności śląskich wspomnień pamiętnikarza, to w większości dotyczą one sfery militarnej, stanowiąc wspomnienia toczonych na tych terenach walk. Narratorami są bowiem przede wszystkim zołnierze, zarówno profesjonahni, jak i amatorzy-ochotnicy. Inne rzeczy znajdıją się w centrum ich zainteresowania, niż by to było w przypadku podróżników puszczających się w drogę z zamiłowania do wędrówki lub z ciekawości obcych krajów. Ta zupełnie odmienna motywacja niejako wymusza też odmienną perspektywę - najważniejsza jest prezentacja wlasnych dokonań militarnych (tak osobistych, jak swojej jednostki czy Polaków w ogóle), nie zaś zachwyt nad cudami przyrody, architekturą miejsca lub odmiennościami narodów czy obyczajów. Dopiero mając na uwadze tę specyfikę, można kusić się o pewne wnioski. Ponadto poziom artystyczıy interesujących nas tekstów zazwyczaj nie jest wysoki (poza wspomnieniami Brodzińskiego i Fredry), jednak nie on przecież zajmować nas będzie przede wszystkim. Wspomnienia tego typu dla historyka, szukającego wiedzy o konkretnych wydarzeniach z przeszłości (rzecz jasna z tym zastrzeżeniem, że pamiętniki nieczęsto zawierają prawdę), są oczywiście cenne, jednak z mojego punktı widzenia na ogół nie okazały się przydatne. Refleksje zogniskowane wokół innych niż militarne kwestii są rzadkie, i przychodzi wydobywać je spośród znacznej ilości informacji o innym charakterze.

Po trzecie wreszcie, naturalne w literaturze pamiętnikarskiej zmyślanie nie będzie stanowiło w tym przypadku problemu, jako że interesujące mnie kwestie nie dotyczą bezpośrednio losów narratorów, zatem brak powodów, dla których mieliby oni koloryzować akurat w kwestiach związanych ze Śląskiem, ale nie dotyczących bezpośrednio wojennych przewag. Co innego w przypadku opisów walk - codziennościąjest tu zawyżanie strat zadanych przeciwnikowi, zanizanie własnych, przekształcanie zwyczajnych potyczek w epickie bitwy i tak dalej.

Po zastrzeżeniach pora przejść do kilku ustalén terminologicznych. Użyte w temacie pojęcie „Polacy” może się wydać nieco mylące, jako ze materiał do mojego wystąpienia pochodzi nie tylko z dzieł, których autorami byli Polacy w rozumieniu etnicznym, lecz raczej byli obywatele I Rzeczypospolitej; znajdziemy bowiem wśród nich i Koroniarzy, i Litwinów (Jan Weysenhoff), i Niemców (Stanisław Broekere); znalazlby się nawet i spolonizowany w pierwszym pokoleniu Flamand (Maurycy I Iauke), jednak niestety nie pozostawił on wspommień dotyczących Śląska. Zakres pojęcia „Polacy” jest zatem szerszy, niżby tego można bylo oczekiwać.

Zakres chronologiczny wyznaczony jest datami 1796-1815, czyli latami, które historiografia uznaje za „czasy napoleońskie”, rozpoczynające się mianowaniem Napoleona Bona- 
partego dowódcą Armii Wloch, zaś zakoníczone wydarzeniami stu dni Napoleona z roku 1815. O Napoleonie jako Napoleonie Pierwszym można mówić od daty jego cesarskiej koronacji, czyli od 2 grudnia 1804 roku, zatem ta część tytułu jest jak najbardziej słuszua, poniewaź śląskie wspomnienia polskich żołnierzy nie wykraczają przed tę datę, zaś najwcześniejsze pochodzą z roku 1806.

W pamiętnikach natrafiany na pojęcia „Śląsk pruski” i „Śląsk ausstriacki”. Geneza tego podziału sięga jeszcze XVIII wieku — jest on mianowicie wynikiem trzech wojen zwanych śląskimi, toczonych między fryderycjańskimi Prusami a Austrią w latach 1740-1742, 1744-1745 oraz 1756-1763. Ostatecznie podział Śląska na dwie części - znacznie większą, obcjmującą niemal 7/8 jego terytorium część pruską, oraz pozostawioną przy Austrii 1/8 dawnego terytorium tej dzielnicy — został ostatecznie ustanowiony na mocy pokoju w Hubertusburgu 15 lutego 1763 roku. Stan taki istniał w interesującym mnie okresie dziejów, zatem będę się posługiwal tymi pojęciami. Godzi się ponadto nadmienić, że to właśnie zabór Śląska wyniósl prowincjonalne do tego momentu Prusy do rangi europejskiego mocarstwa.

\section{Kim są Ślązacy — Polakami, Prusakami, Niemcami czy Ślązakami?}

Zadaniem moim w żadnym razie nie jest opowiadanie się po którejkolwiek ze stron sporu o polskość czy niemieckość Śląskal, zresztą material, którym dysponuję, w żadnym razie nie jest wystarczająco reprezentatywny, by wyciągać z niego jakiekolwiek kategoryczne wnioski w tej kwestii. Pamiętać należy, że pamiętniki, z którymi mialem przyjemność się stykać, stanowia jedynie wyraz pewnych doświadczeń ich autorów, oraz - czego nie sposób przecież wykluczyć - indywidualnych poglądów, wyznawanych w czasie spisywania wspomnień, a które to poglądy mogły przecież wplywać na sposób przedstawiania wydarzeń, dziejących się nickiedy w odległej już przeszlości.

Zatem jedynym pytaniem, na jakie jestem w stanie udzielić odpowiedzi — z uwagi na niekompletność źródeł niepełnej - jest pytanie o sposób, w jaki polscy żołnierze Napoleona I postrzegali mieszkańców Śląska, do jakiej narodowości przynależność skłomni byli im przypisać. Być może obraz uzyskany wskutek tak ujętych założeń okaże się obiektywnie błędny i z punktu widzenia prawdy historycznej bałamutny, jednak da świadectwo pewnym stanom świadomości, stanowić będzie zapis wrażeń konkretnych osób.

W kwestii narodowego kwalifikowania mieszkańców Śląska możliwe są bowiem trzy sytuacje:

\footnotetext{
' Opinic publicystów na temat polskości Śląska i Ślązaków analizowali historycy, miçdzy innymi w pracy Ślask a czmmiki z'u'nętrzme u'XIX-XX uricku, red. L. Smolka. Wroclaw 1992 (tu prace Zbignicwa Frasa

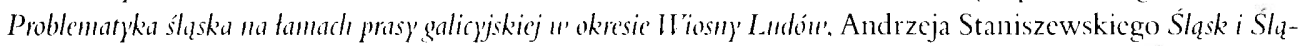

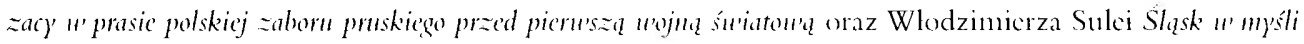
polityczncj polskiej irredenty na practomic XIXi XXY urickni).
} 
1. na Śląskı mieszkają i Polacy, i Niemcy, nie tworząc jednej, wspólnej narodowości;

2. na Śląsku mieszkają wylącznie Niemcy (bądź Prusacy);

3. na Śląsku mieszkają Ślązacy, niebędący ani Polakami, ani Niemcami.

Wydaje się, iż polscy żołnierze doby napoleońskiej postrzegali mieszkańców Śląska dwojako - jako i Polaków, i Niemców oraz jako osobną, odmienną od tych dwu nację. Ostrożnie stawiam taką tezę, jako że nie cały materiał został spenetrowany, i możliwe jest odnalezienie przykladów na odmienne traktowanie ludzi zamieszkujących interesujący nas region.

Józef Zaluski na temat narodowości mieszkańców Śląska ma zdanie może nie najbardziej wyrobione, ale na pewno najdobitniej je wyraża. Opowiadając mianowicie o kampanii 1813 roku, której znaczna część toczyła się na ziemi śląskiej, stwierdza, iź Ślązacy nie są ani Niemcami, ani Polakami. Tak bowiem relacjonuje pobyt Napoleona w Zgorzelcu (23 maja 1813):

Miałem zaszczyt wkroczyć z nim [tj. Napoleonem] do Gorlic [Zgorzelca], miasteczka znaczniejszego, byl przyjęty z podziwem, można powiedzieć, z uwielbieniem tych Ślęzaków, których obejście się z nami Polakami było uprzejme, a nasza mowność w niemieckim języku niemało wpływała na umysl tych mieszczan, którzy nie są ani Niemcami, tym mniej Prusakami, i którzy by latwo to pojęli, że przylączenie ich do Polski byłoby im ze wszech miar korzystne ${ }^{2}$.

$Z$ tego, że Polaków przyjnowali życzliwie, trudno jednak domniemywać o ich jakimś szczególniejszym związku z polskością, jako że życzliwego przyjmowania na kwaterach Polacy doznawali w różnych, nierzadko bardzo od siebie odległych częściach świata, zaś przejawów nieżyczliwości doznawali również i w Księstwie Warszawskim. Zatem formułowanie na podstawie jednostkowych przypadków życzliwej gościnności przekonania o głębszym związku z polskością wydaje się jedıak zbyt daleko idące. Poza tym w epoce, kiedy narodowość identyfikowano przede wszystkim z językiem³ ${ }^{3}$, fakt, że mieszczanie ci mówili po niemieckı, mial swoją wymowę.

Pytanie o stopień identyfikowania się mieszkańców Śląska u schyłku XVIII wieku z pruskim państwem stawia również Gabriela Wąs w stosunkowo nowej pracy, poświęconej historii Śląska ${ }^{4}$. Rozważając całoksztalt polityki pruskich monarchów wobec tej prowincji, autorka ostrożnie konklıdıje, iż

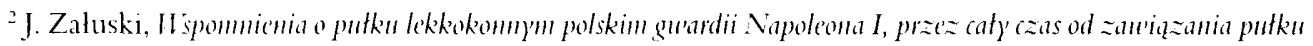
"roku 1807, a之 do kolica "rok" 1814. Kraków 1864, s. 300.

${ }^{3}$ Zob. szerzcj: A. Zicliński. Narod i murodou'ośc u' polskiej literiaturze' i publicystyee lat 1815-1831. Wroclaw 1969. rozdz. 10 (Jez) a marodourośś).

+ Zob. Historia Ślıska, red. M. Czapliński. Wroclaw 2002, s. 244 i nast. 
wiele wskazıje na to, iż pogodzeni z władzą nowego króla, u schyłku XVIII wieku Ślązacy czuli się jeszcze bardziej Ślązakami"

Ponieważ między końcem XVIII wieku a rokiem 1806, czyli początkiem ingerencji francuskiej na ziemi śląskiej, nie zaszło nic, co mogłoby istotnie stan ten zmienić, wypada przyjąć, że - z natury oczywiście powierzchowne - obserwacje naszych pamiętnikarzy mają pokrycie w rzeczywistości, mogą oddawać ówczesną narodową identyfikację mieszkańców Śląska - ani polską, ani pruską, tylko wlaśnie śląską.

Gdyby odwolać się do statystyki, to należałoby stwierdzić, iż Polacy stanowili 72 procent ludności Gómego Śląska, 29 procent Dolnego Śląska - lącznie dla calego Śląska pruskiego było to 23 procent, zaś na Śląsku austriackim Polacy stanowili 73 procent ludności". Dane te jednak nie znają kategorii „Slązak”, nie Polak i nie Niemiec. Nie statystyka mnie jednak interesuje, a konkretne, jednostkowe spostrzeżenia.

Franciszek Gajewski wspomina, iż był świadkiem pojedynku Polaki ze Ślązakiem, stoczonego na wytrzymalość glowy. Opowiada o nim następująco:

Baron Schweinichen, Ślązak i taki sam pijak jak Dobrzycki, usłyszal o sławie Polaka; chcial doświadczyć, czy zasługuje na nią, i w tym celı przybyl do Poznania na transakcyje świętojańskie. Unówili się antagoniści i wobec wielu świadków zaczęli się próbować. Dobrzycki nalal wazę na 12 osób winem węgierskim, wziął ją oburącz i wypil do Ślązaka; ten go wstrzymal. „Nie tak — odezwał się — ja nie pijam małymi kieliszkami”. Jakoż kizał sobie podać rodzaj szklannego węborka, przywiezionego naumyślnie ze sobą, i duszkiem wychylił do Dobrzyckiego. Chorąży przypiąl się także do statka, ale mu tchu zabraklo i musial odpocząć, a zatem przegral zaklad, lubo nie pozostawil w węborku ani kropli wina. Tak pijali jeszcze w 1806 roku ${ }^{7}$.

Oprócz uroczego szczególu obyczajowego, obrazek ten kryje w sobie coś jeszcze. Mianowicie, Gajewski w odniesieniu do różnych nacji niemieckich posługuje się zaniennie określeniami typu „Sasi - Niemcy”; ,Wirtemberczycy - Niemcy”, „Bawarczycy - Niency”, „Prusacy - Niemcy”, ani razu jednak nie stosıje tego w odniesieniu do Ślązaków. Oni zawsze są jedynie Ślązakami. Tym, co ich wyróżnia, jest posługiwanie się przede wszystkim językiem niemieckim, nie zaś polskim, a jeżeli polskim, to złym i zepsıtym. Charakteryzując poznanego szlachcica, niezwykle skądinąd życzliwego, urodzonego na Sląsku Tatara,

Ibidem, s. 245.

"Zob. Historia Slaska, red. W. Dlugoborski, t. 2, cz. 1. Wroclaw 1966, s. 59 (analiza stosunków narodowościowych na Śląsku: s. 47-60).

${ }^{7}$ F. Gajewski, Pamiętniki. t. 1, Poznaí 1913, s. 84. 
pana Murka, tak usprawiedliwia jego niewprawne posługiwanie się polszczyzną: „mówił źle po polsku, bo urodzil się na Śląsku”».

Jedyną rysę w tym stwierdzeniu może stanowić zapis z 1813 roku, odnoszący się do sytuacji na Śląsku w przededniu wkroczenia tam wojsk zwycięskiej koalicji. Pamiętnikarz odnotowal, iz „każdy Prusak oczekiwał na Rosyan jak na oswobodzicieli”, nie wyjaśnia jednak, czy mianem Prusaków obejmuje w s z y s k i ch mieszkańców Śląska, czy tylko Niemców.

Odınienność mieszkańców Śląska (tym jednak razem nie pruskiego, lecz austriackiego) w stosunku do Polaków dostrzega równiez Kazimierz Brodziński, zdecydowanie bardziej nam znany jako pisarz i poeta niż napoleoński żohnierz, choć i on przecież ma w swej biografii epizod wojskowy. Relacjonując przemarsz wojsk polskich przez Austrię, we wpisie datowanym na 10 maja (w Kętach) zauważa:

Górale i Ślązaki (sąsiednie te ludy, a ubiorem i obyczajami tak wiele się różniące) przyjmowali nas z ochotą".

Podobnie dalej, już po przekroczeniu granicy ze Śląskiem austriackim:

Przeszliśmy przez miasto Bielsko o wsi Starego Bielska. (...) Kilka godzin tylko dalej, a już tu inny język i ubiory $(. . .)^{\prime \prime}$.

I dalej pod datą 14 maja zapisuje:

W Ogrodzanach ${ }^{12}$ zebrani, przybyliśmy do Bobrka pod Cieszynem, gospodarz przyjąt nas na kwaterze najuprzejmiej, rządność, gościnność tego czlowieka tak mi się podobały, że chodziłen za nim i przyshıchiwatem się gospodarskim jego rozporządzeniom. (...) U samych chłopów stawamy, a te nieznajome potrawy pan żołądek nie najgrzeczniej przyjmuje (...) zły niezmiernie na tę reformę z żolądkiem. Wina dobrego dostać nie można, a zle po tej cenie, co u nas lepsze ${ }^{13}$.

Przez piçkne miasto Cieszyn tylkośmy przejechali ${ }^{1+}$

to już 15 maja.

\footnotetext{
${ }^{\circ}$ Ibidem, s. 291.

"Ibidem, s. 306 .

"'K. Brodziński. Dziennik unjskou'y' = 1813 roku, w: idem. It'spommienia mojej mtodości, opr. A. Lucki, Kraków 1928, s. 85.

"Mbidem, s. 88.

'2 Ogrodzona - wieś miçdzy Skoczowem a Cieszynem.

${ }^{1.3}$ K. Brodziński. Dzie'muik wojskou'y.... op. cit., s. 91.

"Hbide'll.
} 
Gdyby spojrzeć na rzecz calą z drugiej, niemieckiej strony, to powinniśnny odnotować zdanie wrochawskiego dziewiętnastowiecznego filozofa, Christiana Garve, który stwierdzil:

Śląsk wcielił się bez reszty w pruski organizm państwowy (...), nie ma już prawie żadnej różnicy narodowej między mieszkańcami tej prowincji a innymi; a jeśli ktoś o tym sądzi inaczej, wynikal to z powierzchownych obserwacji, mylących indywidualne odmienności osób pochodzących z tej lub innej prowincji z charakterem narodowym. My Ślązacy staliśmy się nieco bardziej zolnierscy. Naszej szlachcie pochlebia mundur. Natomiast Brandenburczycy i Pomorzanie złagodzili swój dawny wojowniczy charakter wytworniejszym obyczajem i większą wiedzą. Jesteśmy teraz dziećmi jednej rodziny $(\ldots)^{15}$.

Takie właśnie powierzchowne, jednostkowe obserwacje stanowią przedmiot zainteresowania niniejszej pracy, która w żaden sposób nie nua na celu ustalenia polskości bądź nienieckości Śląska, a jest jedynie pytaniem o sposób postrzegania Śląska, ziemi od dawna od Polski oddzielonej, przez określoną grupę społeczną - mianowicie napoleońskich żołnierzy.

Kazimierz Tański pobyt na Śląsku kojarzy wylącznie z militarnymi przewagami swojej formacji (a był nią pułk ułanów Legii Polsko-Włoskicj), stwierdzając, iz

Waleczny i w bojach zahartowany pulk nasz ılanów, sławny tylı świetnymi czynami, wielkie zrobil wrażenie na mieszkańcach Wrocławia i był postrachem dla Niemców ${ }^{16}$.

Przez „Niemców” rozumial nasz pamiçtnikarz przede wszystkim nieregularne oddziały powstańcze, z którymi na Śląsku walczyli wówczas Polacy. Notabene byly to walki na tyle krwawe, iż pułk utracił niemal połowę stanu wyjściowego.

Raport nieznanego z imienia porucznika Trembickiego, pełniącego swoją funkcję w pospolitym ruszeniu krakowskim, a datowany na + stycznia 1807, stwierdza, że Śląsk „nie jest po Odrę pruski, lecz polski"17 zaś miejscowi mieszkańcy, w większości Polacy, chętnie widzieliby wyswobodzenie spod whadzy pruskiej. Spojrzenie na mapkę, przedstawiającą stosunki etnicznc na Śląsku na przełomie XVIII i XIX wicku ${ }^{18}$ (a więc w interesującym nas okresie) potwierdza prawdziwość raportu porucznika Trembickiego.

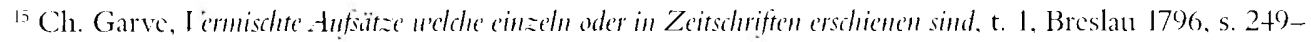
-250); cyt. za: J. Balcke. Ślqzk i Ślazacy. tt. M. Misiorny. Z. Rybicka. Warszawa 2001. s. 96.

${ }^{10}$ K. Tański, Piętraśsic lat u' Legionach. Warszawa 1905, s. +2.

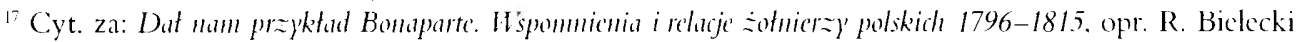
i A. Tyszka, t. 1, Krakíw 1984. s. 176.

"A Zob. mapka dolączona do: Historia Ślıska, red. W. Dhugoborski, op. cit. 
Kończąc tę część rozważań, nadınienić koniecznie należy, iż w kwestii poczucia narodowościowego niezwykle doniosłe przemiany przyniosła wlaśnie epoka napoleońska, to jej zawdzięczamy przemiany w rozumieniu idei narodu. Sytuacja, z jaką stykamy się na kartach naszych pamiętników jest o tyle szczególna, że wprawdzie tematycznie dotyczą wydarzeń z wlaśnie tej epoki, jednak na ogól pisane były znacznie później, stąd niektóre obserwacje mogły zostać niejako „przefiltrowane” przez znacznie późniejsze poglądy; tropienie tego rodzaju zależności, aczkolwiek z calą pewnością możliwe i wykonalne, przekraczałoby jednak dość wąsko zakreślone ramy niniejszego szkicu" ${ }^{19}$.

\section{Witanie zdobywców wiwatami}

I Iistoriografia - zwłaszcza niemiecka - dowodząc niemieckości mieszkańców Śląska, zatrzymywała się w sposób szczególny nad obserwowanym w 1813 roku wybuchem pruskiego patriotyzmu wśród mieszkaniców tego państwa, przejawiającym się przede wszystkim w masowym wstępowaniu do wojska, tworzeniu ochotniczych jednostek, mających na celı walkę z Francuzami ${ }^{21}$, wreszcie entuzjastycznym witaniu wkraczających wojsk rosyjskich.

Samo huczne i manifestacyjne witanie zdobywców nie musi wcale świadczyć o jakimś szczególnym przywiązaniu do wkraczającyclı wojsk czy też monarchów. Dezydery Chłapowski zanotował dwie tego rodzaju sceny, spośród których jednej był naocznym świadkiem, o drugiej zaś słyszał (zapewne od innych oficerów sztabowych). Mianowicie Wiedeńczycy w roku 1809 witali wkraczających do miasta Francuzów i ich wladcę hucznymi wiwatami²1, czego przyczyn nasz oficer upatruje z jednej strony we właściwej mieszkańcom stolicy Austrii obojętności, z drugiej zaś w magnetycznym nieledwie uroku Napoleona. Dodaje też, iż słyszal, że podobne sceny miaty miejsce w Berlinie, w roku 1806, gdy do stolicy Prus wkraczały zwycięskie wojska francuskie ${ }^{22}$. Być może więc motywem wylewnego witania zdobywcy była zarówno ciekawość zobaczenia zwycięskich wojsk i ich wodza (choć naturalnie nikt nie chciałby wrogiej armii gościć na swoim terenie zbyt dłıgo, skoro podstawowym sposobem jej żywienia były rekwizycje), jak też i swego rodzaju przejaw zdrowego instynktu samozachowawczego, próba swoistego „ułagodzenia” zdobywcy. Być może więc i mieszkańcy Wroclawia kierowali się podobnymi motywami, witając monarchów, dowodzących wojskami zwycięskiej koalicji? Z naszego punktu widzenia jest to zresztą kwestia marginalna.

Poza tym pokonani rzadko bywajł̨ obiektem wiwatów. Józef Załuski, opisując powrót z nieszczęsnej kampanii rosyjskiej (czy też, jak zwał ją Napoleon, drugiej wojny polskiej) stwierdza, iż Śląsk przejechal po cywilnemu, podając się za zwyklego podróżnego, jako że „kraje [tj. Śląsk austriacki, Morawy, Czechy i Bawaria - przyp. T. Ś.] nie sprzyjały spra-

"Zob. przede wszystkin A. Zielinski. Narod i morodourose..., op. cit.

2" Zob. M. Olczak. Kampania 1813. Slask i Łnź)' Warszawa 20(14, s 50 i nast.

$=$ Zob. 1). Chlapowski, Pamictmiki. cz. 1: ITojin napoleoniskie' (1806-1813), Poznań 1899, s. 64.

Z Zob. ibidem. 
wie Napoleona"³. Dodatkowo podróż ta dala mu asumpt do stwierdzenia, iż na terenach dawnej Rzeczypospolitej, zajmowanych przez wojska zwycięskiej koalicji, stosunek whadz cywihnych i wojskowych przypominal obchodzenie się z krajami podbitymi, podczas gdy Śląsk pruski i austriacki były traktowane przez wojska koalicyjne zupetnie dobrze ${ }^{2+}$.

Gromadzenie się ochotników do walki z Francuzami we Wrocławiu miał okazję na własne oczy widzieć Józef Grabowski ${ }^{25}$. Notuje on ponadto, że po rozejmie z dnia 4 czerwca „obywatele opuszczali Śląsk i uchodzili za Odrę"?t. Mogło to być racjonalne z ich punktu widzenia opuszczanie terenu spodziewanych działań wojennych. Jak się miało później okazać, w rzeczywistości toczyly się one na zachodzie, obejmując Śląsk w stosunkowo nieznacznym stopniu, zatem opuszczający Śląsk mieszkańcy wpadali - jak to celnie ujmuje przysłowie — z deszczu pod rynnę.

Najlogiczniej jednak rzecz całą ujął Aleksander Fredro, konstatując (wprawdzie pisal o Saksonii, ale zasada przezeń sformulowana zastosowanie może znaleźć i w przypadkı innych krajów):

Sasi nas nie lubili, i nie tylko że nas nic lubili, ale byliby chętnic całą naszą armię z Cesarzem na jej czele w łyżce wody utopili, gdyby tylko mogli byli taką łyżkę znaleźć. Nie ma się czemu dziwić. Ów ciągły menuet wojsk wszystkich narodów od Portugalczyka do Czerkiesa, od Neapolitańczyka do Lapończyka po całej pięknej Saksonii nie mógł ich ani bawić, ani uszczęśliwiač ${ }^{27}$.

Podobnie mogło być również na Śląsku. Równie realistyczne spojrzenie ma Grabowski ${ }^{2 x}$, analizujący przyczyny narastającej niechęci w krajach niemieckich do Napoleona; wedle jego wniosków winne są przede wszystkim rekwizycje oraz system kontynentalny.

\section{Śląsk - polska ziemia utracona}

Kolejnym zagadnieniem, w pewien sposób związanym z identyfikacją narodową mieszkańców Śląska, jest problem natury czysto historycznej — czy walczący na Sląsku (lub Sląsk tylko przemierzający) polscy żołnierze mieli świadomość dawnej, polskiej przynależności tej prowincji.

2.3. Zaluski, Itspommicnia...., op. cit., s. 290 .

${ }^{2+}$ Zob. ibidem.

${ }^{25}$ Zob. J. Grabowski. Pamictmiki u'ojskou'c, Warszawa 19015. s. 15-16. Nowe wydanic tego dzicla z 2005 roku nie było mi jeszcze dostçpue.

2t Ibidem, s. 51 .

${ }^{27}$ A. Fredro, Trzy potrzy, w: idem. Pisma w's zsthie, opr. S. Pigoń, t. 13: Proza, opr. K. Czajkowska. S. Pigoní, cz. 1, Warszawa 1968, s. 77.

2* Zob. J. Grabowski, op. cit., s. 107-111. 
Najdalej idącą wypowiedź w tej kwestii formułuje Józef Załuski, wskazując na fakt utraty Śląska przez naszych przodków. Tak o tym wspomina:

Jakkolwiek opuszczaliśnny kraj rodzinny nie bez pewnej tęsknoty [działo się to w 1807 roku, jednostka Zaluskiego ruszala do I Iiszpanii, 14 października przejeżdzała przez Wroclaw, gdzie of icerowie wzięli udział w balı, zorganizowanym przez marszalka Mortiera na cześć rocznicy bitew pod Jeną i Auerstädt - przyp. T. Ś.], wzniecil w nas uczucie tęsknoty widok Szląska, lepiej zabudowanego i zagospodarowanego od naszych stron, a razem żalu, że ta piękna kraina, niemal kolebka Polski, tak niezgrabnie została przez naszych przodków utracona"n.

W dalszej części tej wypowiedzi Załuski opowiada o życzliwym stosunku Ślązaków do Polaków, pisząc o Śląsku i Saksonii:

Jakkolwiek krainy Szląsk i Saksonia zdają się być nam obcymi, nie możemy się skarżyć na jakąś odrazę do nas ze strony tamecznych mieszkańców; przeciwnie, zdawało się nam, że nieszczęścia naszego kraju i nasza ochoczość zashugiwania się dla niego wzbudzaly sympatią, której doznawaliśmy prawie wszędzie. Niemalo do tego uczucia przyczyniała się nasza umiejętność języka niemieckiego, pozwalająca nam oświecać o naszym kraju, bronić jego zasług i przekonywać; jakoż dawne zabytki w Szląsku, świeże pamiątki królów polskich w Saksonii, a cuda dziejące się w ówczesnej polityce, nie czyniły wstrętnym wiekowe braterstwo Wisły, Odry i Elby ${ }^{31}$.

Natomiast podobnego wrazenia nie odniósł Klemens Kołaczkowski, który stwierdza, ze z nauk we Wrocławiu (pobieranych na miejscowym uniwersytecie) wrócil pośpiesznie do Poznania na wieść „o powstaniu ogólnym zabranych części Polski”31. Dla niego zabranymi częściami Polski byly wyłącznie ziemie wchodzące w skład Rzeczypospolitej przed 1772 rokiem - Śląsk najwyraźniej został utracony zbyt dawno, by Poznańczyk Kolaczkowski mial tego świadomość.

Swiadomość odzyskiwania dawnych ziem polskich z n a z n i e silniejsza byla jednak w stosunku do terenów wchodzących w skład dawnej, przedrozbiorowej Rzeczypospolitej. Najwyraźniej wspomnienia sięgające czasów jeszcze piastowskich nie były ani silne, ani wyraziste. Natomiast spotykamy - zawsze zresztą w kontekście kampanii 1812 roku - refleksje na temat osiągania, dochodzenia do slupów Bolesławowych (tak na przykład

"J. Zahuski. Wspommicmia.... op. cit.. s. 51.

3"I Ibidem. s. 51-52.

${ }^{31}$ K. Kołaczkowski, Uspomnnienia. Kraków 1898. ks. 1, s. 20. 
Sułkowski pisał o entuzjazmie wśród polskich żołnierzy V korpusu, którzy „ploną chęcią udziału w przesuwaniu naszych granic do słupów Bolesława”32). Ciekawe skądinąd, że po drugiej wojnie światowej pojęcie to powróci, jednak z kolei wylącznie w odniesieniu do zachodnich granic Polski.

Ślady refleksji (choć trudno dociec, na ile był to element propagandy) o dawnym obszarze terytorialnym Polski, z czasów jeszcze piastowskich, znajdıjemy w liście Antoniego Sulkowskiej z 3 maja 1807 roku, pisanego podczas oblegania Kolobrzegu, a opublikowanego później w „Gazecie Poznańskiej” 27 maja tegoż roku. Sułkowski cytuje kapelana 1 pułku piechoty, księdza Ignacego Przybylskiego, który tak zachęcał żołnierzy swojego pułku do działań bojowych:

Żołnierze polscy. Pod Kolbergiem obozujemy. Od czasów Chrobrego nasz regiment, na łonie województw gnieźnieńskiego i poznańskiego utworzony, pierwszy chorągwie wojskowe polskie na Pomorzu rozwija ${ }^{33}$.

\section{Śląsk — zaawansowanie cywilizacyjne}

Józef Zaluski podczas przemarszu swej.jednostki przez Śląsk zauważa, iż dzielnica ta jest wyraźnie lepiej zagospodarowana oraz cechuje się lepszą zabudową niż inne, które dane mu bylo widzieć ${ }^{3+}$. Uwagę tę poczynił jednak w roku 1807 , mając przed sobą przemarsz przez Niemcy, Francję oraz pobyt w Hiszpanii. Być może, gdyby pisał o tym później, zrewidowałby swój pogląd na temat wyższości Śląska nad innymi krajami.

Franciszek Gawroński z czasów, gdy jeszcze nie służył w wojsku, wspomina, iż w jednej ze wsi galicyjskich, wchodzących w sklad majątku rodzinnego, budynki stawiane byly przez rzemieślników sprowadzonych ze Śląska ${ }^{35}$. Nie wspomina wprawdzie, który Śląsk ma na myśli - pruski czy austriacki, jednak zasadne byloby przypuszczenic, iż fakt sprowadzenia budowniczych z innej prowincji tego samego państwa (Austrii) nie byłby wart odnotowania. Prawdopodobnie więc pracownicy pochodzili z zagranicy, z pruskiej wówczas części ziemi śląskiej. Przypuszczenie takie można dodatkowo wzmocnić innymi sądami, pochodzącymi od kilku pamiętnikarzy, którzy wskazywali na znaczny kontrast między pruską a austriacką częścią śląskiej ziemi.

Bogactwo i zamożność ziemi śląskiej potwierdza również Jakub Kierzkowski, choć nie to stanowiło dla niego informację pierwszej wagi. Podczas relacjonowania działań wojennych pod Wrocławiem w 1813 roku dostrzega bujne zboże pod jeduą ze wsi ${ }^{36}$ (Deutsche

\footnotetext{
${ }^{32}$ A. P. Sulkowski, Listy do $\dot{\approx} n y^{\prime}=110$ jen mapoleniskich, th. i opr. R. Biclecki. Warszawa 1987. s. $24+-245$.

${ }^{3.3}$ Cyt. za: R. Biclecki, Hstęp do: A. P. Sulkowski, op. cit., s. 16.

${ }^{3+}$ Zob. J. Zaluski, I'spummienia..., op. cit., s. 51.

35 Zob. F. S. Gawronski, Pamiçmik noku 1830/31 i kromika pamiętnikoura (1787-1831). Kraków 1916, s. 271.

*3 Zob. J. F. Kierzkowski, Pamiçmiki. Warszawa 190)3, s. $2(03$.
} 
Lissa - obecnie Leśnica). Jednak oczywiście nie bogactwo jest dla niego informacja pierwszej wagi, a fakt, iż tamże Prusacy zostali wprowadzeni w błąd i ostrzelali wieś, w której nie było ani jednego Francuza. Bogactwo śląskiej ziemi dla Kierzkowskiego jest szczegółem drugoplanowym, za to z mojego punktu widzenia sprawa ma się dokładnie odwrotnie.

Podobne wrażenia zamożności śląskiej ziemi odniósł Marcin Smarzewski w trakcie przemieszczania się korpusu księcia Poniatowskiego przez ziemie austriackie, gdy wojsko polskie przechodzilo przez Śląsk Cieszyníski, Morawy i Czechy do Saksonii. Zanotował on, iz krainy te (nie konkretyzując, czy ma na myśli t y l ko Morawy i Czechy, czy w ogóle ziemie pod panowaniem Austrii) stoją na znacznie wyższym poziomie kulturalnym oraz gospodarczym niż Polska czy Galicja ${ }^{37}$ (przez Polskę rozumiał z pewnością zienie Księstwa Warszawskiego). Znacznie więcej uwagi poświęcił jednak Saksonii, krainy istotnie w owym czasie stojącej na bardzo wysokim stopniu rozwoju ekonomicznego; zachwyt ten podzielają zresztą i inni pamiętmikarze.

Kontrast między Galicją a Śląskiem Cieszyńskim i Morawami uderzył również Klemensa Kołaczkowskiego. Odnotował on następujące spostrzeżenie:

Inny obraz przedstawil nam się na Śląsku austriackim, i w Morawii. Tu ubóstwo nie mniejsze niż w Galicji, lecz domki schlıdıe, wybielone, mieszkańcy gościnni, porządnie odziani, bogobojni, moralni! A jednak jest to ten sam ród slowiański. W kimże wina? ${ }^{38}$

Postawione pytanie jest jednak czysto retoryczne, pamiętnikarz nie udziela odpowiedzi, pozostawiając czytelnika jego własnym przemyśleniom.

Zupełnie odmienne poglądy na temat Śląska miał z kolei Antoni Paweł Sułkowski. W jednym z listów do żony, datowanym na 26 grudnia 1812 roku, porusza kwestię karmienia ich nowo narodzonego dziecka. Formułuje w tej kwestii następujące ząadanie:

Protestuję równocześnie przeciwko wszystkim mamkom z Wrocławia, bo w całym Śląsku nie ma ani jednego zdrowego zęba ${ }^{39}$.

Nie zdradza jednak malżonce, skąd tego rodzaju informacje pochodzą (zatem i nam nie będzie dane ich poznać). Dodaje ponadto:

zobowiązuję Cię, abyś z chwila przybycia do Wrocławia pomyślała o znalezieniu jakiejś innej mamki z Gurzna ${ }^{+(1)}$ albo też innej wioski polskiej ${ }^{+1}$.

\footnotetext{
${ }^{37}$ Zob. M. Smarzewski. Pamiętmike 1809-1831. Wrocław 1962. s. 79.

${ }^{35}$ K. Kolaczkowski, op. cit., ks. 2. s. 11.

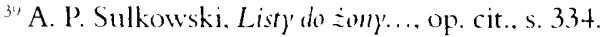

"* Gurzno lub Górzno. wieś w okolicach Pleszewa, Wiclkopolska.

${ }^{+1}$ A. P. Sulkowski, Listy do ¿iml'..., op. cit.
} 
Najwyraźniej książę Sulkowski był przekonany o naturalnej wyższości polskiego mleka (lub podziclal poglądy o wysysaniu przez dzieci pewnych cech z mlekiem matki, i ıie chciał, by były to cechy niepolskie), bo w jednym z następnych listów, z 9 stycznia 1813 roku, podnosi tę kwestię ponownie, pisząc:

Przypuszczam też, że manka już przybyła i że moja mała I Ialina pozbyła się śląskiego mleka, i pije tylko czyste, stowiańskie ${ }^{+2}$.

Na marginesie tej wypowiedzi zauważyć możemy, że dla Sulkowskiego przymiotniki „Śląski” i „slowiański” nie są synonimami, zatem i polskość Śląska czy raczej Ślązaków nie jest dla niego faktem jednoznacznie potwierdzonym, natomiast opowiada się w ten sposób za śląskością Ślązaków.

Nie dysponujemy wystarczającą wiedzą, by docicc, jakie przeslanki wplynęły na taki a nie inny sąd Sulkowskiego o stanie uzębienia Slązaków, jednak posiłkując się ogólną wiedzą na temat ówczesnego polożenia niższych warstw spoleczeństwa (a z nich przecież rekrutowaly się wspomniane manki), można ostrożnie stwierdzić, iż książę Sułkowski mial rację. Jak czytamy we wspólczesnej nam pracy o Śląsku i jego mieszkańcach, „sytuacja ludności wiejskiej w obrębie calego Sląska w porównaniu z sytuacją ogólnoniemiecką uchodziła za szczególnie zlą"+3, jednak w czym mogła być lepsza od sytuacji na ziemiach wchodzących w sklad Księstwa Warszawskiego, które przecież ani bogactwem, ani stanem higieny nie przewyższały prowincji śląskiej? Znamy ponadto świadectwa z początków XIX wieku, wcale liczne, które zdecydowanie przemawiają na korzyść Śląska. I Iistoryk, ekonomista i literat. Franciszek Skarbek, w pozostawionych notatkach z podróży po Śląsku (przede wszystkim listach) zawarł między innymi i taką uwagę (w liście datowanym na 23 października 1809 roku):

jaka jest znaczna różnica między wioskami śląskimi a naszego Księstwa, o jedną nawet milę od siebie nieodległymi. Wjeżdżałąc do pruskich krajów, za pierwszym niejako krokiem odmianę poznać można i jakby cudnym wplywem demarkacyjnej linii inny wcale kraj masz z jednej jak z drugiej strony onejże. (...) Słowem, znaczne polepszenie w całkowitym pobyciu |tj. bycie, egzystencji - T. Ś.] chlopstwa uderza każdego, który z uwagą za nasze wyjeżdża granice ${ }^{t+}$.

\footnotetext{
+2 Ibide'm. s. $3+9$.

${ }^{+3}$ J. Balcke, Slazsk i Ślqzacy. op. cit.. s. 292.

${ }^{++}$F. Skarbek. cyt. za: A. Zichníski. Naród i morodowośc.... op. cit., s. 85-86. W dalszej czçści wypowiedzi podróżny podkreśla zamożność i higienę̧ micjscowej ludności.
} 
Mimo wszystko wspomniane powyżej uwagi na temat zamożności śląskiej ziemi, zwłaszcza w zestawieniu jej z zicmiami wchodzącymi w skład Księstwa Warszawskiego, nie pozwalają na stwierdzenie, iż polscy żołnierze Napoleona byli w jakiś szczególny sposób oszołomieni śląskim dostatkiem. Inaczej jednak sprawy się miały w przypadku żołnierzy rosyjskich, dla których Śląsk stanowił swego rodzaju przedsionek ziemskiego raju. Berend Johann Uxkull, oficer jednego z pulków kirasjerów, w prowadzonym dzienniku tak pisał o Śląsku:

Wieś, gdzie obozowaliśmy, jest pół mili dluga. Wójt, który nas przyjął, żyje jak wielki pan. (...) Ten Śląsk jest rajem. Wszystkie domy są zbudowane z kamienia. Chłopi są bogaci. (...) Meble, lóżka, jedzenie, kawa, owoce, piwo, wino wspaniałe. Jaka różnica między naszym i tym krajem ${ }^{+5}$.

Nawiasem mówiąc, spora część zapisów poświęconych jest erotycznym przygodom Uxkulla (miał wtedy dwadzieścia lat). Gdyby szukać miejsca na ziemi, które jawiłoby się naszym pamiętnikarzon w podobnym, rajskim świetle, byłaby nim Andaluzja.

\section{Wspomnienia różne}

Antoni Bialkowski wspomina, iż podczas stacjonowania jego pułku w Rawiczu, tuż — jak podaje — „nad śląską granica” " myśle: spośród zamożniejszych ster społeczeństwa) z zagranicy, z prowincji śląskiej właśnie. Bliższych szczegółów jednak nie podaje, nie informuje też ani o narodowości gości, ani o języku, w jakim rozmawiali. Być może dla Białkowskiego było to oczywiste, jednak nie jest to takie oczywiste dla nas, jako że skądinąd wiemy, iż władał on i językiem polskim, i niemieckim. W ogóle zresztą Śląsk kojarzył mu się karnawałowo, bowiem kolejne wspomnienie, związane $z$ tą dzielnicą, pochodzi z roku 1813 i również związane jest ze świętowaniem ${ }^{47}$.

Franciszek Gawroński widzi Śląsk jako swego rodzaju - przejściową wprawdzie Ziemię Obiecaną, jako że podczas wojny 1806 roku „wielu już z młodzieży przekradało się przez granicę do Śląska"tr. Na Śląsku bowiem działały nie tylko oddziały francuskie, ale i polskie, wśród nich Legia Polsko-Włoska, złożona z pułku ułanów oraz trzech pułków piechoty. Na Śląsku też formowano legię tę na nowo, zasilając osłabione stratami wojennymi trzy pułki piechoty świeżymi rekrutami, zmieniono też nazwę, „Legię Polsko-Wloską” zastępując "Legią Nadwiślańską”. Formacja ta po pewnym czasie przeszla na słıżbę króla

\footnotetext{
${ }^{5}$ Cyt. za: M. Olczak. Kampania 1813... op. cit., s. 72-73.

th. A. Bialkowski. Pumictmiki starego sotmicral (1806-1814). Warszawa 1903. s. 73.

+' Zob. ibide'm, s. 285.

${ }^{+*}$ F. S. Gawroński. Pammiçmik.... op. (it., s. 280 ).
} 
Westfalii, a ostatecznic znalazla się w I Iiszpanii. Po powstaniu Księstwa Warszawskiego patrioci z Galicji będą przekradać się już bezpośrednio do Księstwa, czego liczne świadectwa znajdujemy we wspomnieniach naszych żohnierzy tamtego czasu.

Jakub Kierzkowski podczas służby w korpusie marszalka Darouta, objętym później przez Mortiera, mial okazję stacjonowania na Śląsku, w samej stolicy tej prowincji, we Wrocławiu. $Z$ całego tego pobytu odnotowuje jedynie to, że zołnierze zostali przeniesieni z domów prywatnych do koszar, czym sprawili mieszkańcom miasta znaczną ulge ${ }^{+ \text {) }}$ (normą w owych czasach był bowiem kwaterunek żołnierzy w domach prywatnych, koszary jako miejsce pobytu wojskowych stanowiły wówczas jeszcze pewne no' $u m)$. Odnotowuje również brak entuzjazmu żołnierzy, wywołany przenosinanni (co akurat nie dziwi, bo w koszarach wygód było z 11 a c z n i e muiej). Stwierdza również, iż „zanosilo się na dhugi czas pobytu Francuzów w Prusach" ". Sformułowanie takie w żadnyn razie nie dziwi, bo skoro Śląsk stanowił prowincję pruską, to oczywiście francuskie garnizony znajdowały się „w Prusach”. W żadnym razie nie wskazuje to na ewentualną pruskość nnieszkańców tej ziemi.

W kwestii kwaterowania żohierzy w domach prywatnych odmienne zdanie ma inny spośród naszych autorów, mianowicie Wojciech Dobiecki, żołnierz Legii Nadwiślańskiej’’. Stwierdza on, iz

nie było to wielkim cięzarem dla miasta, bo rzemieślnicy i kupcy wielkie mieli zarobki, gdy wszystkie zakłady (dépôts) calej wiclkicj armii koncentrowaly się we Wroclawiu i przez caly czas pobytu wojsk naszych w tym miéście zadna zwada ani skarga miejsca nie miały ${ }^{52}$.

Rzecz cala działa się w 1807 roku. Godzi się nadmicnić, że w czasach późniejszych, po roku 1815, mieszkańcy poszczególnych miast śląskich zabiegali o utworzenie w nich garnizonów, widząc w tym źródto dochodów dla mieszkańców; zauważyć jednak wypada, że ciężar utrzymania garnizonów spoczywal na państwie, zaś w czasach napoleonískich utrzymanie dla stacjonującego w mieście garnizonu zapewniali sami micszkańcy.

Innego rodzaju wspomnienia, związane ze Śląskiem, notuje Klemens Kołaczkowski. W wojnie 1806-18(17 roku, której fragment dotknąl pruskiego Sląska, nie brał bezpośrednio udziału (bo był za młody), natomiast znajdował się we Wrocławiu, oblężonym przez IX korpus dowodzony przez cesarskiego brata, I Iieronima Bonaparte, zlożony glównie z posilkowych wojsk niemickich (oblężenie trwało między 7 grudnia 1806 roku a 7 stycznia roku następnego), gdy w mieście tym pobierał nauki, wysłany tam przez zapobiegliwe-

+" Zob. J. F. Kicrzkowski, op. cit., s. 1+2.

"Ibidelll. s. $1+3$.

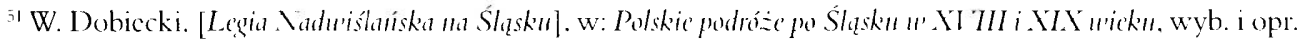

A. Zicliński, Wrocław 1974. s. 76-80.

Ibidem, s. 79. 
go ojca. Kilku kolegów z czasów wrocławskich przyjdzie mu spotkać po latach we Francji, w 1814, gdy w mundurach zwycięskiej armii pruskiej będą paradować po stolicy Francji ${ }^{53}$.

Kołaczkowski wymienia kilka miejsc, które we Wroclawiu odwiedził, miejsca przechadzek, zajazd, w którym zamieszkiwał. Wspomina:

Spacery nasze zwykle kierowaliśmy w wolniejszych chwilach na wały, w kierunku I Hundsfeld (Psie pole, sławne pobojowisko z czasów Bolesława Krzywoustego, 1109) na drodze ku Polsce, ku ogrodowi księcia Hohenloe i pomnikowi na cześć generała Tauenzien przez Świdnicką bramę wystawionemu, albo też za bramę Olawską (Olauer Thor), lub nareszcie ku pięknemu dębowemu lasku na lewym brzegu Odry ${ }^{54}$.

W stolicy Śląska pozostał do 1808 roku, pobierając niezbędne nauki. Obserwował również wydarzenia, które na trwałe ukształtowały krajobraz mojego miasta rodzinnego, mianowicie wysadzanie micjskich fortyfikacji. 1)ziałania te kwituje krótko: piękny widok ${ }^{55}$.

Zasadniczo rzecz biorąc, spośród naszych pamiętnikarzy najwięcej do powiedzenia powinien mieć Stanisław Broekere, jako ze początki jego kariery wojskowej związane są z armią pruską, zaś jednostka, w skład której wchodzil, stacjonowała na Śląsku. Niestety jednak, najwyraźniej uznał on, iź Śląsk pruski jaki jest, każdy widzi, i przytłaczającą większość uwagi poświęcil obserwacjom dotyczącym Hiszpanii, kraju, w którym spędzil sporą część swojego wojskowego życia. Wspomnienia z walk w tym kraju, aczkolwiek wielce interesujące, przekraczają jednak ramy mojego artykułu.

\section{Zakończenie}

Polscy żohnierze w służbie Napoleona I trafiali na Śląsk w różnych okolicznościach, przede wszystkim związanych z działalnością militarną, jednak refleksje z pobytu na tej ziemi najczęściej dotyczą toczonych na Śląsku walk bądź tras przemarszów. Uwagi niezwiązane bezpośrednio z wojną koncentrują się wokól kilku różnych zagadnień. Są nimi przede wszystkim rozmyślania nad narodowością mieszkańców Śląska, nad zamożnością tej dzielnicy, w szczególności skontrastowanej z poziomem rozwoju ziem wchodzących w skład Księstwa Warszawskiego, jak też i inne, rzadziej pojawiające się kwestie. W każdym razie stwierdzić należy, iż Polacy nie czuli się na Śląsku obco, nie odbierali go tak, jak traktowali imne kraje, do których przyszło im trafić: Niemcy, Francję, Włochy, Hiszpanię, Rosję czy odległe Santo 1)omingo. Śląsk, zamieszkany przez Ślązaków, był krainą bliską, bogatszą wprawdzie, ale nie obcą.

${ }^{53}$ K. Kolaczkowski, op. cit.. ks. 2, s. 122.

${ }^{54}$ Ibide'm, ks.1. s. 15.

${ }^{5}$ Zob. ilidem, ks.1, s. 22. 